\title{
A case of massive haemoptysis
}

\author{
Benjamin Diggins, ${ }^{1}$ Katherine Rider, ${ }^{1}$ Chris D Sheldon, ${ }^{1}$ Anthony F Watkinson ${ }^{2}$
}

${ }^{1}$ Department of Respiratory Medicine, Royal Devon and Exeter NHS Foundation Trust, Exeter, UK

${ }^{2}$ Department of Interventional Radiology, Royal Devon and Exeter NHS Foundation Trust, Exeter, UK

\section{Correspondence to}

Dr Benjamin Diggins, bdiggins@nhs.net

Accepted 14 June 2018

\section{DESCRIPTION}

A 77-year-old female never-smoker presented with massive haemoptysis. Admission plain chest radiograph was normal.

She was haemodynamically stable on presentation but the following morning she had a further large-volume haemoptysis $(>500 \mathrm{~mL})$, resulting in respiratory arrest. Following resuscitation, haemoglobin fell from 94 to $66 \mathrm{~g} / \mathrm{dL}$. CT angiogram was performed (figure 1).

She had previously been investigated for small volume haemoptysis and left upper lobe mass-like consolidation, which had fully resolved following a course of antibiotics. Recent bronchoscopy was normal, with no pathological organisms. There was no evidence of malignancy or connective tissue disease, and there was no additional past medical history. CT imaging had been reviewed at a thoracic oncology multi-disciplinary meeting and the previous episode was attributed to non-specific infection.

\section{Question}

What is the diagnosis (see figure 1)?

(A) Pulmonary artery pseudoaneurysm.

(B) Bronchial artery haemorrhage.

(C) Bleeding endobronchial tumour.

(D) Ruptured aortic aneurysm.

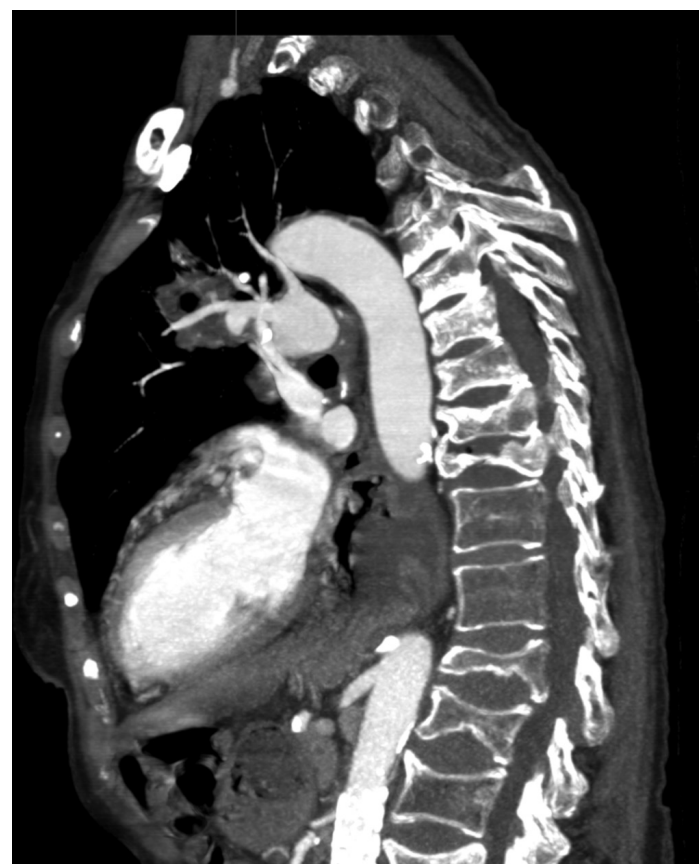

Figure 1 Sagittal CT angiogram, performed once the patient was stabilised.

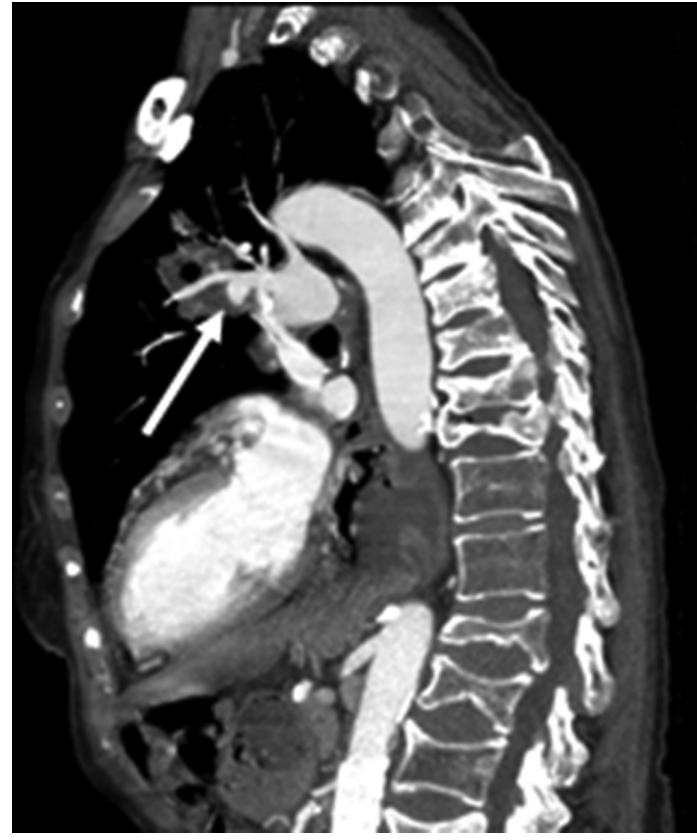

Figure 2 Sagittal view of CT angiogram demonstrating pseudoaneurysm (arrow) of the left upper lobe pulmonary artery (anterior segment).

\section{Answer: A}

CT demonstrates pseudoaneurysm of the left upper lobe pulmonary artery (figure 2, arrow).

Bronchial arteries arise from the descending thoracic aorta, not the pulmonary circulation. Normal bronchoscopy and recent radiological resolution make an endobronchial tumour highly unlikely; neither the history nor imaging suggests aortic aneurysm rupture.

Massive haemoptysis is not commonly encountered, but its management is highly challenging. Mortality is $>50 \%{ }^{1}$; however, prompt emergency treatment can be life-saving through prevention of further haemorrhage and airway compromise.

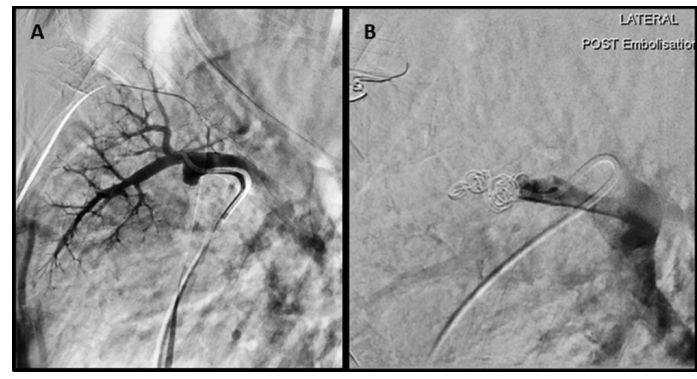

Figure 3 Pseudoaneurysm at angiography: pre-coiling (A) and post-coiling (B), demonstrating occlusion of left upper lobe pulmonary artery. 
Traditional 'A to E' assessment is critical: emergency measures include maintaining a patent airway, providing supplemental oxygen and correcting any coagulopathy. If the bleeding site is known, laying the patient in the lateral decubitus position on the side of the haemorrhage may help. Tranexamic acid may reduce bleeding duration and volume, ${ }^{2}$ but identifying the bleeding source may be critical in permitting life-saving treatment. ${ }^{3}$ Once the patient is stabilised, CT angiography can be used to identify the site of bleeding. In our patient, CT angiography was not performed immediately due to clinical stability; had this been performed on her arrival, then the episode resulting in respiratory arrest may potentially have been avoided.

Bleeding originates from bronchial arteries in $>90 \%$, but differentiation from pulmonary artery pseudoaneurysm (PAP) is important.

\section{Learning points}

- Massive haemoptysis is a life-threatening emergency with mortality $>50 \%$. However, simple 'A to $E^{\prime}$ measures can support the patient until definitive treatment is available.

- Bleeding can occur from either bronchial or pulmonary circulation, but most commonly from the bronchial vessels.

- Early identification of the source of bleeding through CT angiography offers access to life-saving interventions such as endovascular coil embolisation.
PAP is rare $(5 \%-10 \%$ of cases); associations include tuberculosis (Rasmussen aneurysm), abscess, malignancy and vasculitis. ${ }^{13}$ No underlying cause of PAP was identified in this patient.

Endovascular coil embolisation is recognised in treating both bronchial artery haemorrhage and $\mathrm{PAP}^{3}$ This was performed successfully in this patient (figure 3). She was discharged from hospital 1 week later with no further haemoptysis or other complications at 12-month follow-up.

Contributors All authors were involved in writing and editing the manuscript prior to submission, and approve of the submitted version. BD and KR reviewed the literature around the subject. CDS, BD and AFW were directly involved in the care of the patient.

Funding The authors have not declared a specific grant for this research from any funding agency in the public, commercial or not-for-profit sectors.

Competing interests None declared.

Patient consent Obtained.

Provenance and peer review Not commissioned; externally peer reviewed.

(C) BMJ Publishing Group Ltd (unless otherwise stated in the text of the article) 2018. All rights reserved. No commercial use is permitted unless otherwise expressly granted.

\section{REFERENCES}

1. Khalil A, Parrot A, Nedelcu C, et al. Severe hemoptysis of pulmonary arterial origin: signs and role of multidetector row CT angiography. Chest 2008;133:212-9.

2 Moen CA, Burrell A, Dunning J. Does tranexamic acid stop haemoptysis? Interact Cardiovasc Thorac Surg 2013;17:991-4.

3 Pelage JP, El Hajjam M, Lagrange C, et al. Pulmonary artery interventions: an overview. Radiographics 2005;25:1653-67.

Copyright 2018 BMJ Publishing Group. All rights reserved. For permission to reuse any of this content visit http://group.bmj.com/group/rights-licensing/permissions.

BMJ Case Report Fellows may re-use this article for personal use and teaching without any further permission.

Become a Fellow of BMJ Case Reports today and you can:

- Submit as many cases as you like

- Enjoy fast sympathetic peer review and rapid publication of accepted articles

- Access all the published articles

- Re-use any of the published material for personal use and teaching without further permission

For information on Institutional Fellowships contact consortiasales@bmjgroup.com

Visit casereports.bmj.com for more articles like this and to become a Fellow 